\title{
Economists' policy views and voting
}

\author{
DANIEL B. KLEIN ${ }^{1, *}$ and CHARLOTTA STERN ${ }^{2, *}$ \\ ${ }^{1}$ Department of Economics, Santa Clara University, Santa Clara, CA 95053, U.S.A.; ${ }^{2}$ Institute for Social \\ Research, Stockholm University, S-106 91 Stockholm, Sweden \\ (*Author for correspondence: e-mail: dklein@scu.edu)
}

Accepted 6 December 2004

\begin{abstract}
In Spring 2003, a survey of 1000 economists was conducted using a randomly generated membership list from the American Economics Association. The survey contained questions about 18 policy issues, voting behavior, and several background variables. The response was 264 (nonblank) surveys. The responses show that most economists are supporters of safety regulations, gun control, redistribution, public schooling, and anti-discrimination laws. They are evenly mixed on personal choice issues, military action, and the minimum wage. Most economists oppose tighter immigration controls, government ownership of enterprise and tariffs. In voting, the Democratic:Republican ratio is 2.5:1. These results are compared to those of previous surveys of economists. We itemize a series of important questions raised by these results.
\end{abstract}

\section{Surveys of Economists}

In the past 30 years, there have been more than ten surveys asking American economists to evaluate economic policy statements or identify their own political views. A few of the more prominent ones are Kearl et al., 1979; Alston et al., 1992; Blendon et al., 1997; Fuchs, Alan, and James, 1998; Fuller and Geide-Stevenson, 2003. In this paper, we present the basic results of a rich survey of American Economic Association members. In contrast to most previous survey of economists, our survey was designed to elicit an overall judgment of support or opposition for each form of government activism, and to make the format uniform so that an individual's set of responses could be combined into an index.

The results raise many questions about the current state of the economics profession. However, we basically let the reader react to the data his or her own way. In the concluding section we itemize questions for further research, and we are in pursuit of some of those questions ourselves. The purpose of this paper is to provide an early reading of the raw results and to encourage economists to better understand their own profession.

\section{Description of Survey and Data}

In March and April 2003, 1000 U.S. members of the American Economic Association were surveyed using a randomly generated list of members. The 
overall aim of the survey project is to study how the individual's political views change over time; the survey asks the respondent to report the policy views she had when she was 25 years old, and then asks her present views. A byproduct of the investigation, then, is information about respondents' present views. This paper simply summarizes the present public policy views of AEA members; we do not consider the "when 25 " views here. ${ }^{1}$ The survey controller received 264 nonblank surveys in return, a response rate of $26.6 \%$ (adjusting for PO Returns, etc.).

\section{Description of the Economist Sample}

1) Check the highest degree you hold $(N=264)$

\begin{tabular}{lrr}
\hline Ph.D. & 217 & $82.20 \%$ \\
Masters & 34 & $12.88 \%$ \\
Bachelor's & 3 & $1.14 \%$ \\
J.D. & 9 & $3.41 \%$ \\
Other & 1 & $0.38 \%$ \\
\hline
\end{tabular}

The sample of economists mostly contains individuals with a Ph.D. and 92.8\% (245 respondents) reported economics as the field in which they got the degree.

2) Please check your primary employment $(N=264)$

\begin{tabular}{lcr}
\hline Academic & $128^{\mathrm{a}}$ & $48.8 \%$ \\
Public sector & 43 & $16.3 \%$ \\
Private sector & 75 & $28.4 \%$ \\
Independent research & 18 & $6.8 \%$ \\
\hline
\end{tabular}

aWe changed three respondents to "academic" based on their having filled out the subsequent two questions, which are contingent on the respondent being an academic. Also, respondents who checked academic and other responses are counted as academic.

Of those reporting Academic, we ask two follow-up questions:

$3)$ What is the highest degree your department issues? $(N=128)$

\begin{tabular}{lrr}
\hline Bachelors & 30 & $23.4 \%$ \\
Masters & 23 & $18.0 \%$ \\
Ph.D. & 73 & $57.0 \%$ \\
No response & 2 & $1.6 \%$ \\
\hline
\end{tabular}


4) Is your college/university public or private? $(N=128)$

\begin{tabular}{lrr}
\hline Public & 77 & $60.2 \%$ \\
Private & 46 & $35.9 \%$ \\
Both & 3 & $2.3 \%$ \\
No response & 2 & $1.6 \%$ \\
\hline
\end{tabular}

\section{Economists' Views on the 18 Public Policy Questions}

The respondents were asked 18 questions about public policy issues. The following query about tariffs shows the format:

Tariffs on imported goods to protect American industries and jobs:

\begin{tabular}{llllll}
\hline$\square$ & $\square$ & $\square$ & $\square$ & $\square$ & $\square$ \\
Support & Support & Have mixed & Oppose & Oppose & Have no \\
strongly & mildly & feelings & mildly & strongly & opinion \\
1 & 2 & 3 & 4 & 5 & \\
\hline
\end{tabular}

The numbers 1-5 did not appear in the survey. They show how we weighted each response when creating an index (or mean response).

Here we present the results on the 18 policy questions in three groups: economic regulations (Table 1), regulation of personal choices (Table 2), and role of government (Table 3).

Of all 18 issues, tariffs are the form of government activism economists are most uniformly opposed to. A strong consensus against tariffs and quotas has been perhaps the most established finding in surveys of economists (Kearl et al., 1979, p. 30; Alston et al., 1992, p. 204; Moorhouse, Morris, \& Whaples, 1999, p. 84; Fuller \& Geide-Stevenson, 2003, p. 37; Heckelman \& Whaples, 2004, p. 19). On minimum wage, economists are very mixed, with a slight edge in support of minimum wage laws. Our finding again agrees with two previous surveys of labor economists, both of which found that about half of those surveyed favored increasing the minimum wage (Whaples, 1996, p. 1730; Fuchs et al., 1998, p. 1391). ${ }^{2}$ On FDA, OSHA, and EPA regulations, most economists are supportive. These findings again agree with previous findings of economists tending to support "consumer protection" laws and the regulatory power of the EPA (Kearl et al., 1979, p. 30; Alston et al., 1992, p. 205; Fuller \& Geide-Stevenson, 2003, p. 380).

Looking at Table 2, we see that economists are mostly supporters of government restrictions on discrimination and of gun control, but are mixed on drugs, prostitution and gambling laws. 


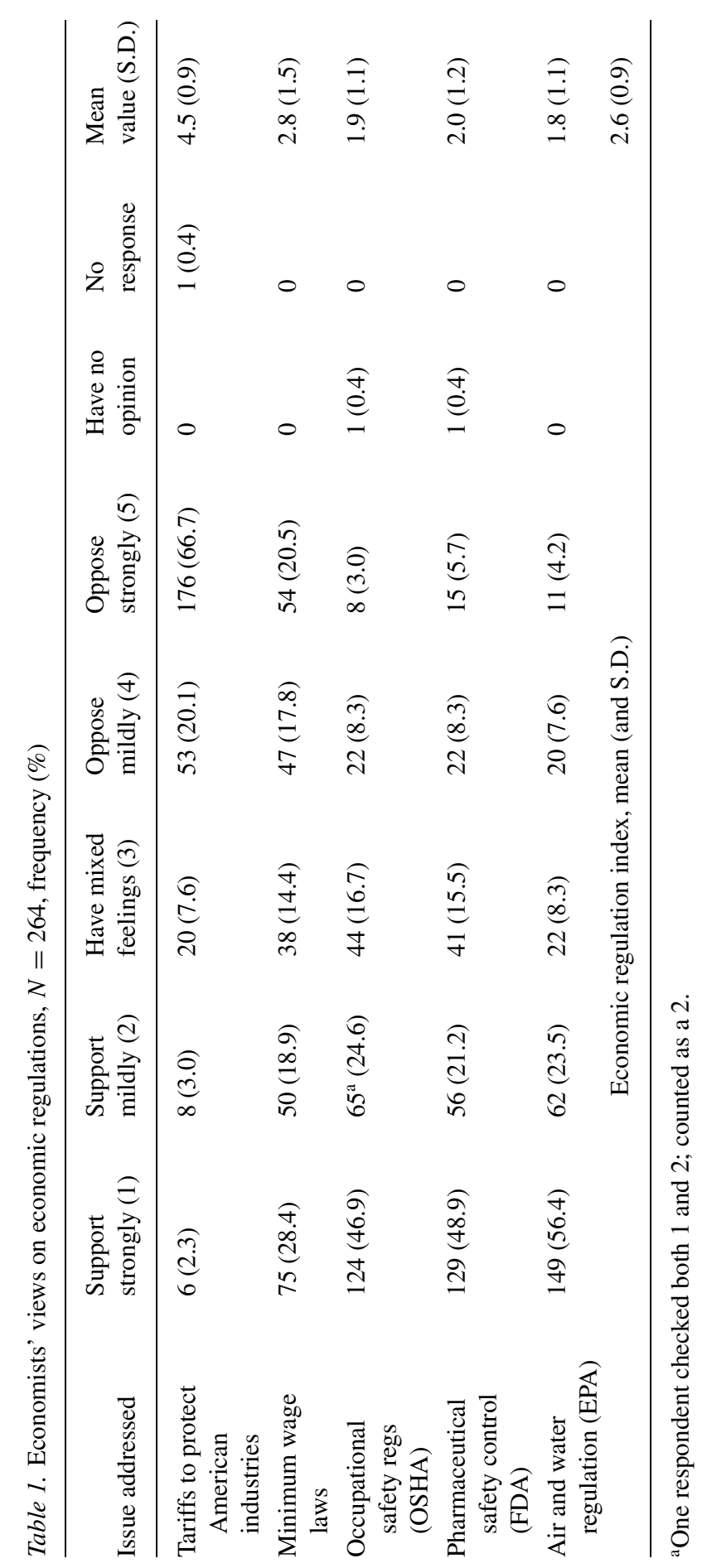




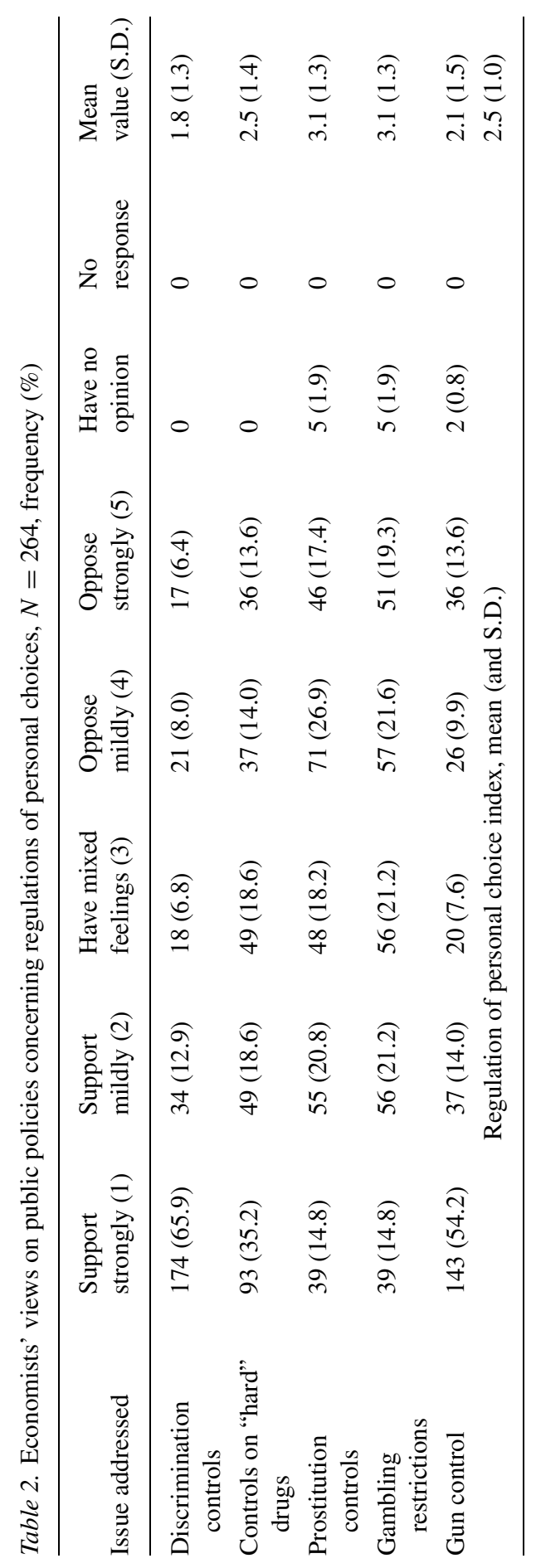


In Table 3, the form of government activism most opposed by economists is government ownership of enterprise, followed by tighter controls of immigration. Our result about immigration concords with the finding that $96 \%$ of labor economists agree that gains to American society from immigration exceeds the losses (Whaples, 1996, p. 731).

Economists are more centered on military aid and presence abroad and tuning the economy by fiscal policy. On fiscal policy, there seems to be a decline in support over time, where Kearl et al. $(1979$, p. 30) found a very high degree of agreement with the statement that fiscal policy has a significant stimulative impact on a less than fully employed economy; agreement with the same statement falls a bit by the time of Alston et al. (1992, p. 204), and would seem to be even lower in our study.

Economists generally support redistribution, the government production of schooling, foreign aid, and tuning the economy by monetary policy. On redistribution, Fuchs et al. (1998, p. 1400) finds that a little over half of labor economists and of public economists are inclined to increase redistribution. ${ }^{3}$

The bottom of Table 3 shows the mean Policy index over all 18 issues as 2.6. On the whole, economists are more supportive than opposed to government activism as listed here. Restricting the sample to the 128 responding economists who are in academics does not change the Policy index mean value. ${ }^{4}$

\section{Economists Voting Behavior}

Most economists vote Democratic (Table 4). The Democrat:Republican ratio is 2.5:1. The 2.5:1 ratio is based on answers for all economist respondents. Table 5 shows the ratios of democrat to republican voters for the various sectors of economists-beware the dwindling sub-sample sizes.

\section{Voting Behavior from the Six Fields}

When we surveyed the AEA members, we also surveyed members of five other scholarly associations. We also surveyed anthropologists, historians, political scientists, political and legal philosophers, and sociologists. ${ }^{5}$

Of the six fields surveyed, Table 6 shows that voting Democratic is most preponderant among the anthropologists and sociologists, who both have a Democrat:Republican ratio of nearly 16:1. The least preponderant is Economics, but even there the ratio is about 2.5:1.

A 2001 Brookings Institution survey of AEA members with 160 respondents found a ratio of 3.7:1. Hence, they found a higher ratio. The Brookings study also surveyed sociologists, historians, and political scientists. For sociologists, the ratio reported by Brookings was higher than ours, and for historians and political scientists their ratios were lower (Brookings Institution, 2001, p. 54). The differences might be partly accounted for by the fact that the 


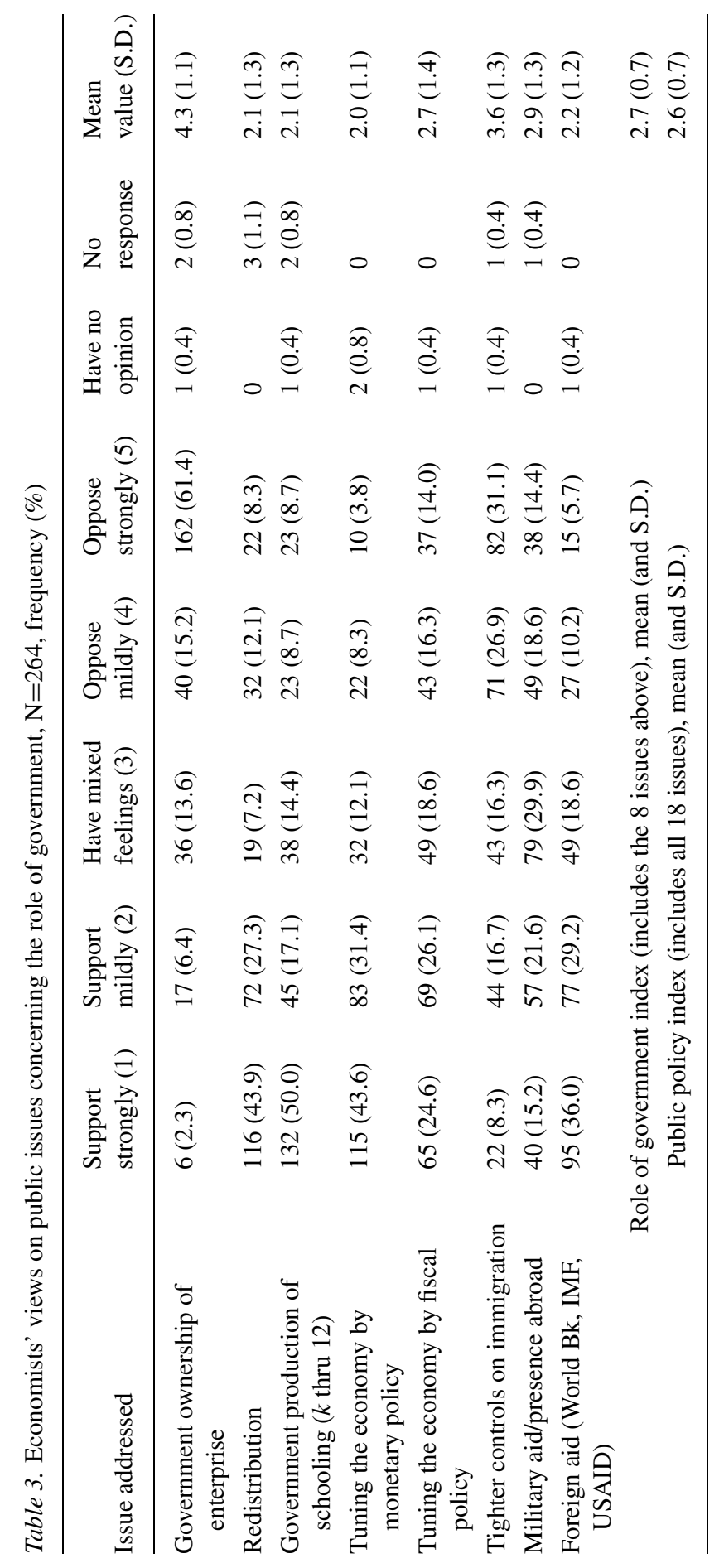


Table 4. To which political party have the candidates you have voted for in the past ten years mostly belonged?

\begin{tabular}{lcr}
\hline & Frequency & Percent \\
\hline Democratic & 153 & 58.0 \\
Republican & 61 & 23.1 \\
Green & 2 & 0.8 \\
Libertarian & 7 & 2.7 \\
\multicolumn{1}{c}{$\quad$ Respondents checking more than one option } \\
Democratic/republican & 3 & \\
Other (w/o comment) & 1 & 1.1 \\
Diffuse (checked 3 or more) & 5 & 0.4 \\
Non-response & 24 & 1.9 \\
Do not vote & 1 & 9.1 \\
Cannot vote & 7 & 0.4 \\
Total & 264 & 2.7 \\
\hline
\end{tabular}

Table 5. Economists' D:R ratio by employment sector

\begin{tabular}{lrl}
\hline Employment & $N$ & D:R ratio \\
\hline Academic & 105 & $2.9: 1$ \\
Public sector & 36 & $4.1: 1$ \\
Private sector & 57 & $1.4: 1$ \\
Independent research & 16 & $4.3: 1$ \\
& 214 & $2.5: 1$ \\
\hline
\end{tabular}

Brookings survey selected academics with certain specialties (Light, 2001, p. 3) (Table 6).

\section{Sorting the Issues by Level of Support}

Table 7 provides the complete wording of each question and sorts them by level of support by the average economist.

\section{Questions for Further Research}

The raw results presented in this paper raise a number of important questions:

1. Economists have something of a reputation for favoring free-market principles, yet we see that economists on average are supportive of most economic interventions, mixed on a few interventions, and opposed only on immigration (weakly opposed to tighter restrictions), government ownership of 
Table 6. Voting behavior of the associations studied $(N=1678)$

\begin{tabular}{llllllll}
\hline & $\begin{array}{l}\text { Democratic } \\
(\%)\end{array}$ & $\begin{array}{l}\text { Green } \\
(\%)\end{array}$ & $\begin{array}{l}\text { Libertarian } \\
(\%)\end{array}$ & $\begin{array}{l}\text { Republican } \\
(\%)\end{array}$ & $\begin{array}{l}\text { Misc. } \\
(\%)\end{array}$ & $\begin{array}{l}\text { No response } \\
(\%)\end{array}$ & $\begin{array}{l}\text { Total } \\
(100 \%)\end{array}$ \\
\hline Anthropology & $295(84.3)$ & $6(1.7)$ & $1(0.3)$ & $19(5.4)$ & $20(5.7)$ & $9(2.6)$ & 350 \\
Economics & $152(57.8)$ & $2(0.8)$ & $7(2.7)$ & $61(23.1)$ & $18(6.4)$ & $24(9.1)$ & 264 \\
History & $231(77.8)$ & $2(0.7)$ & $0(0.0)$ & $38(12.8)$ & $17(5.7)$ & $9(3.0)$ & 297 \\
$\begin{array}{l}\text { Philosophy } \\
\quad \text { political and }\end{array}$ & $82(76.6)$ & $2(1.9)$ & $4(3.7)$ & $11(10.3)$ & $4(3.7)$ & $4(3.7)$ & 107 \\
$\quad$ & & & & & & & \\
$\quad \begin{array}{l}\text { legal) } \\
\text { Political science }\end{array}$ & $238(77.0)$ & $2(0.6)$ & $4(1.3)$ & $43(13.9)$ & $13(4.2)$ & $9(2.9)$ & 309 \\
$\begin{array}{l}\text { Sociology } \\
\text { Total }\end{array}$ & $288(82.1)$ & $8(2.3)$ & $0(0.0)$ & $18(5.1)$ & $19(5.4)$ & $18(5.1)$ & 351 \\
\hline
\end{tabular}

industry, and tariffs. It seems that most economists in fact stand in the middle of the road or even on the interventionist side. Why, then, do they have a reputation for being free-market supporters?

2. When you break the data down by individuals, what percent of all economists are free-market supporters? What percent of Democrats? What percent of Republicans? Do Republicans support free-market principles much more strongly than Democrats? On what issues do Democrats support free-market principles more than Republicans do?

3. Economists in academia are Democratic to Republican at a ratio of 2.9 to 1 . If the Republican Party is more in line with the free market, and if economics teaches an appreciation of market forces, then why are most economists voting Democratic?

4. The survey responses came from a random sample of AEA members. Only about $55 \%$ of academic economists are AEA members (Siegfried 1998 , p. 217). Hence, $45 \%$ decide against joining the AEA. Does this data warrant investigation into whether the AEA is skewed to the left? Maybe the economics profession is really more supportive of free-market principles than this survey suggests.

5. On some of the issues treated by the survey, such as FDA regulation of pharmaceuticals, economists who research the topic and express a judgment reach a clear conclusion in favor of liberalization (Klein \& Tabarrok 2004). They probably would have answered 4 or 5 to the FDA question. Yet the average economist supports FDA control (with a score of 2.0). Indeed, $49 \%$ answered "strongly support." Assuming that the experts on the topic are correct, how can it be that most economists do not know the results of their own science on this urgent issue?

6. The results for all six fields surveyed show that Economics has the largest standard deviation in responses. If consensus is the hallmark of science, why is it that there is less consensus (on whether specific interventions 
Table 7. The 18 issues ordered by level of economist support

Policy index

mean value

\begin{tabular}{|c|c|c|}
\hline \multicolumn{3}{|c|}{ Most economists support } \\
\hline 1 & $\begin{array}{l}\text { Laws making it illegal for private parties to discriminate (on the } \\
\text { basis of race, gender, age, ethnicity, religion or sexual-orientation) } \\
\text { against other private parties, in employment or accommodations }\end{array}$ & 1.8 \\
\hline 2 & $\begin{array}{l}\text { Air-quality and water-quality regulation by the Environmental } \\
\text { Protection Agency (EPA) }\end{array}$ & 1.8 \\
\hline 3 & $\begin{array}{l}\text { Workplace safety regulation by the Occupational Safety and Health } \\
\text { Administration (OSHA) }\end{array}$ & 1.9 \\
\hline 4 & Using monetary policy to tune the economy & 2.0 \\
\hline 5 & $\begin{array}{l}\text { Pharmaceutical market regulation by the Food and Drug } \\
\text { Administration (FDA) }\end{array}$ & 2.0 \\
\hline 6 & Government production of schooling $(k$ through 12$)$ & 2.1 \\
\hline 7 & $\begin{array}{l}\text { Redistributive policies (transfer and aid programs and tax } \\
\text { progressivity) }\end{array}$ & 2.1 \\
\hline 8 & Laws restricting gun ownership & 2.2 \\
\hline 9 & $\begin{array}{l}\text { Foreign aid and assistance by such organizations as the World Bank, } \\
\text { the International Monetary Fund, and US AID }\end{array}$ & 2.2 \\
\hline \multirow[t]{2}{*}{10} & $\begin{array}{l}\text { Laws restricting the use and exchange of "hard" drugs such as } \\
\text { cocaine and heroin }\end{array}$ & 2.5 \\
\hline & Economists are mixed on: & \\
\hline 11 & Using fiscal policy to tune the economy & 2.7 \\
\hline 12 & Minimum wage laws & 2.8 \\
\hline 13 & $\begin{array}{l}\text { American military aid or presence abroad to promote democracy } \\
\text { and the rule of law }\end{array}$ & 2.9 \\
\hline 14 & Laws restricting gambling & 3.1 \\
\hline 15 & Laws restricting prostitution & 3.1 \\
\hline \multicolumn{3}{|c|}{ Most economists oppose } \\
\hline 16 & Tighter rather than looser controls on immigration & 3.6 \\
\hline 17 & Government ownership of industrial enterprises & 4.3 \\
\hline \multirow[t]{2}{*}{18} & Tariffs on imported goods to protect American industry and jobs & 4.5 \\
\hline & Overall policy index mean value & 2.6 \\
\hline
\end{tabular}

promote the public interest) in Economics than there is in Anthropology, History, Philosophy, Political Science and Sociology?

These are good questions for further research. The data provided by the survey will help us address some of them. But many of them, such as the possible ideological skew in AEA membership and the broader questions about the character of the profession, need to be addressed with new methods, new investigations, and searching reflection. 


\section{Acknowledgments}

We are grateful to the Leavey School of Business and the Robert Finocchio Fund at Santa Clara University for assistance in meeting the costs of the survey, and especially to Ms. Donna Perry, Assistant Dean, Leavey School of Business, Santa Clara University, for acting as independent controller and certifying the results.

\section{Notes}

1. At the Survey Homepage one may view a sample survey and documents explaining the methods, independent control, and certification of the survey results. The Survey Homepage URL is http://lsb.scu.edu/ dklein/survey/survey.htm.

2. Other surveys ask economists whether the minimum wage causes unemployment, but one's answer to that question does not determine an answer to our question about the minimum wage.

3. Kearl et al. (1979) and Alston et al. (1992) ask whether redistribution is a legitimate role of government. Fuller and Geide-Stevenson (2003) ask whether distribution of income should be more equal. Again, answers to these questions would not determine an answer to our questions.

4. Restricting the sample to academics does not significantly change any of the indexes: it change the economic regulation index mean to $2.65(0.91)$, the personal choice index mean to 2.54 (1.01), and the role of government index mean to 2.72 (0.67).

5. In each case, we surveyed members of the American [disciple] Association, except that the philosophers were members of the American Society for Political and Legal Philosophy, which contained only 486 members.

\section{References}

Alston, R. M., Kearl, J. R., \& Vaughan, M. B. (1992). Is there a consensus among economists in the 1990s? American Economic Review, Papers and Proceedings, 82(May), 203-209.

Blendon, R. J., Benson, J. M., Brodie, M., Morin, R., Altman, D. E., Gitterman, D., Brossard, M., \& James, M. (1997, Summer). Bridging the gap between the public's and economists' views of the economy. Journal of Economic Perspectives, 11(3), 105-118.

Brookings Institution. (2001). National Survey on Government Endeavors, Prepared by Princeton Survey Research Associates, dated November 9, online at http://www.brookings.edu/comm/reformwatch/rw04/surveydata.pdf.

Fuchs, V. R., Krueger, A. B., \& Poterba, J. M. (1998). Economists' views about parameters, values, and policies: Survey results in labor and public economics. Journal of Economic Literature, 36(3), 1387-1425.

Fuller, D. A., \& Geide-Stevenson, D. (2003). Consensus among economists: Revisited. Journal of Economic Education, 34(4), 369-387.

Heckelman, J., \& Whaples, R. (2004). Public choice economics: Where is there consensus? Unpublished ms., Wake Forest University.

Kearl, J. R., Pope, C. L., Whiting, G. C., \& Wimmer, L. T. (1979). A confusion of economists. American Economic Review, Papers and Proceedings, 69(May), 28-37. 
Klein, D. B., \& Tabarrok, A. (2004). Quotations: Economists' judgments about the FDA. A page of FDAReview.org, by Klein and Tabarrok. http://www.fdareview.org/quotations.shtml. Oakland: Independent Institute.

Light, P. C. (2001). Government's greatest priorities of the next half century, Reform Watch, No. 4, Brookings Institution, December, online at http://www.brookings.edu/ dybdocroot/comm/reformwatch/rw04/rw4.pdf.

Moorhouse, J., Morris, A., \& Whaples, R. (1999). Economics and the law: Where is there consensus? The American Economist, 43(2), 81-89.

Siegfried, J. J. (1998). "Who is a member of the AEA?" Journal of Economic Perspectives, 12(2), 211-222.

Whaples, R. (1996). Is there consensus among American labor economists? Survey results on forty propositions. Journal of Labor Research, 17(4), 725-734. 